\title{
DIVERSITY AND MORPHOLOGY OF THE SPECIES OF PSEUDO- NITZSCHIA (BACILLARIOPHYTA) OF THE NATIONAL PARK SISTEMA ARRECIFAL VERACRUZANO, SW GULF OF MEXICO
}

\author{
Michael L. Parsonsi ${ }^{1}$, Yuri B. Okolodkov² \& José A. Aké-Castillo ${ }^{2}$ \\ ${ }^{1}$ Florida Gulf Coast University, Coastal Watershed Institute, \\ Department of Marine and Ecological Sciences, 10501 FGCU Blvd South, \\ Fort Myers, FL 33965-6565, USA. \\ ${ }^{2}$ Universidad Veracruzana, Instituto de Ciencias Marinas y Pesquerías, \\ Laboratorio de Botánica Marina y Planctología, calle Hidalgo 617, \\ Colonia Río Jamapa, 94290 Boca del Río, Veracruz, México. \\ Autor para la corrrespondencia: yuriokolodkov@yahoo.com
}

\begin{abstract}
In order to evaluate the risk for marine ecosystem and human health, the diversity and morphology of diatoms of the genus Pseudo-nitzschia were studied. Weekly sampling was performed at seven geo-referenced sites in the National Park Sistema Arrecifal Veracruzano, SW Gulf of Mexico, during the annual cycle from May 2005 to May 2006. Samples were taken in the 30-cm surface layer of the water column with a phytoplankton net of 20- $\mu \mathrm{m}$ mesh size. With the use of light, transmission and scanning electron microscopy, seven Pseudo-nitzschia species were identified: non-toxic P. cf. subcurvata (examined only by light microscopy) and P. brasiliana, and potentially toxic, causative agents of amnesic shellfish poisoning (ASP) due to domoic acid: $P$. calliantha, $P$. cuspidata, P. delicatissima, $P$. pseudodelicatissima and $P$. pungens. It is concluded that there is a potential risk of ASP in the study area. P. brasiliana and P. calliantha are new records for the SW Gulf of Mexico. Comparisons with studies conducted in the northern Gulf of Mexico indicate that the diversity of Pseudo-nitzschia in the Gulf of Mexico may be greater than currently documented and that some species (e.g., P. multiseries) may have biogeographic limitations (e.g., temperatures below $27^{\circ} \mathrm{C}$ ).
\end{abstract}

Key words: amnesic shellfish poisoning, diatoms, Gulf of Mexico, morphology, new records, Pseudo-nitzschia, taxonomy, Veracruz. 


\section{RESUMEN}

Con el fin de evaluar el riesgo para el ecosistema marino y la salud humana, se estudió la diversidad y la morfología de las diatomeas del género Pseudo-nitzschia del Parque Nacional Sistema Arrecifal Veracruzano, en el suroeste del Golfo de México. Se realizaron muestreos semanalmente en siete sitios georeferenciados durante un ciclo anual de mayo de 2005 a mayo de 2006. Las muestras se tomaron de la capa superficial de 30 $\mathrm{cm}$ de la columna de agua con una red fitoplanctónica de $20 \mu \mathrm{m}$ de tamaño de malla. Con ayuda de los microscopios fotónico, electrónico de transmisión y electrónico de barrido se identificaron siete especies de Pseudo-nitzschia: las no tóxicas P. cf. subcurvata (estudiada solamente en el microscopio fotónico) y $P$. brasiliana, y las potencialmente venenosas, causantes de la intoxicación amnésica por consumo de mariscos (ASP) debido al ácido domoico: P. calliantha, P. cuspidata, P. delicatissima, P. pseudodelicatissima y P. pungens. Se concluye que existe riesgo potencial de ASP en el área de estudio. $P$. brasiliana y $P$. calliantha son nuevos registros para el suroeste del Golfo de México. Las comparaciones con los estudios en el norte del mismo cuerpo marino indican que la diversidad de Pseudonitzschia en el Golfo de México puede ser más alta que la documentada en el presente, y que algunas especies (e.g., P. multiseries) pueden tener limitaciones ecológicas y biogeográficas (e.g., temperaturas menores de $27^{\circ} \mathrm{C}$ ).

Palabras clave: diatomeas, Golfo de México, intoxicación amnésica por consumo de mariscos, morfología, nuevos registros, Pseudo-nitzschia, taxonomía, Veracruz.

\section{INTRODUCTION}

Pseudo-nitzschia H. Peragallo is a widely distributed marine genus (Hasle \& Syvertsen, 1996; Hasle, 2002), with 38 currently described species (Guiry, 2011). Interest in the genus increased when, in 1987, severe intoxications and at least three human mortalities were reported in those who consumed blue mussels (Mytilus edulis L.) containing the neurotoxin domoic acid (DA) (Wright et al., 1989). Further research determined that the DA was produced by the planktonic diatom Pseudonitzschia multiseries (Bates et al., 1989). The resultant shellfish poisoning was termed amnesic shellfish poisoning (ASP), as one of the distinguishing symptoms of acute exposure to DA is short-term memory loss (Perl et al., 1990). Later, marine fish, bird and mammal mortalities occurred, caused by their consumption of DAcontaminated Pseudo-nitzschia species or vectors, causing DA poisoning (DAP); 
thus, toxigenic Pseudo-nitzschia species also became a threat to marine animal health (Trainer et al., 2008).

At present, the following Pseudo-nitzschia species are known as DA producers: P. pseudodelicatissima (Hasle) Hasle, P. pungens (Grunow ex Cleve) Hasle, $P$. multiseries (Hasle) Hasle, P. seriata (Cleve) H. Peragallo, P. australis Frenguelli, $P$. calliantha Lundholm, Moestrup et Hasle, $P$. cuspidata (Hasle) Hasle, P. fraudulenta (Cleve) Hasle, P. multistriata (Takano) Takano, P. delicatissima (Cleve) Heiden, $P$. turgidula (Hustedt) Hasle and $P$. galaxiae Lundholm et Moestrup (Bates \& Trainer, 2006; Trainer et al., 2008, 2009).

Economic losses caused by DA-associated Pseudo-nitzschia blooms have been reported from various countries around the world: Canada, USA, Mexico, Costa Rica, Argentina, Denmark, Scotland, Ireland, France, Spain, Italy, Tunisia, Morocco, Korea and Vietnam (Skov et al., 1997; Akallal \& Mouradi, 2000; Bates \& Richard, 2000; Kotaki et al., 2000; Sarno \& Dahlmann, 2000; Cho et al., 2002; Fehling et al., 2004; Vargas-Montero \& Freer, 2004; Lundholm et al., 2005; Badylak et al., 2006; Nezan et al., 2006; Almandoz et al., 2007; Bogan et al., 2007; Cortés-Altamirano \& SierraBeltrán, 2008; Quijano-Scheggia et al., 2009; Sarahraoui et al., 2009).

At least six of the 12 Pseudo-nitzschia species known to produce DA (P. australis, P. delicatissima, $P$. pseudodelicatissima, $P$. multiseries, $P$. pungens and $P$. seriata) have caused blooms or intoxications in the Mexican Pacific and the coastal waters of the Gulf of California (Ochoa et al., 1996; Meave del Castillo \& Hernández-Becerril, 1998; Licea et al., 2000; Moreno-Ruiz et al., 2004; Sierra-Beltrán et al., 2005; CortésAltamirano \& Sierra-Beltrán, 2008). Pseudo-nitzschia species have also been observed in both the southern (Meave del Castillo et al., 2000; Gómez-Aguirre et al., 2004; Licea et al., 2004) and northern Gulf of Mexico (Fryxell et al., 1990, 1991; Dortch et al., 1997; Parsons et al., 1998, 2002; Liefer et al., 2009; Del Rio et al., 2010; MacIntyre et al., 2011). The following Pseudo-nitzschia species have been documented in the northern Gulf of Mexico: P. brasiliana Lundholm, Hasle et G. A. Fryxell, $P$. decipiens Lundholm et Moestrup, P. delicatissima, P. prolongatoides (Hasle) Hasle, P. pseudodelicatissima, $P$. pungens, $P$. multiseries, $P$. subfraudulenta (Hasle) Hasle, $P$. subpacifica (Hasle) Hasle, and P. galaxiae Lundholm et Moestrup (Conger et al., 1972; Licea, 1992; Parsons et al., 1998; Lundholm \& Moestrup, 2002; Lundholm et al., 2002; Krayevsky et al., 2009). Pseudo-nitzschia species regularly bloom in Louisiana coastal waters (Dortch et al., 1997; Del Rio et al., 2010), likely stimulated by intensifying eutrophication over the past 50 years in response to higher nutrient loads from the Mississippi River (Parsons et al., 2002). The concern that these Pseudo-nitzschia blooms could result in a DA event was manifested when DA was detected in gulf menhaden (Clupeidae: Brevoortia 
patronus Goode; Del Rio et al., 2010) and in bottlenose dolphins (Tursiops truncatus (Montagu); Schwacke et al., 2010), demonstrating that DA is moving up into higher trophic levels in the Gulf of Mexico.

As DA produced by Pseudo-nitzschia has affected higher trophic levels in the northern Gulf of Mexico, further assessment of the potential threat of DA to ecosystem health was deemed necessary for the SW Gulf of Mexico. The main purpose of this study, therefore, was to document the diversity and morphology of Pseudonitzschia species of the National Park Sistema Arrecifal Veracruzano (NPSAV), Gulf of Mexico, to evaluate the risk for the marine ecosystem and human health.

\section{MATERIAL AND METHODS}

Samples were taken from May 2005 to May 2006, at seven oceanographic stations during a weekly monitoring of red tides of the Aquarium of Veracruz (Fig. 1; for geographic coordinates, see Okolodkov, 2008), in the 30-cm surface layer, using a phytoplankton net of $20-\mu \mathrm{m}$ mesh and $28 \mathrm{~cm}$ in diameter. Preliminary identifications of Pseudo-nitzschia species were made using a Nikon Eclipse T100 inverted microscope. Diatom frustules were cleaned by removing the organic matter by oxidation (Lundholm et al., 2002). Two milliliters of saturated $\mathrm{KMnO}_{4}$ solution with $30 \% \mathrm{H}_{2} \mathrm{SO}_{4}$ were added to a 10 -ml aliquot of the sample. After $24 \mathrm{~h}$, the sample was bleached by adding $10 \mathrm{ml}$ of saturated oxalic acid solution, and then it was repeatedly washed with distilled water.

Thirteen samples from the seven stations taken in 2005 were selected, on the basis of their high abundance of Pseudo-nitzschia species, for further analysis using differential interference contrast (DIC) microscopy and electron microscopy (EM) to identify the various Pseudo-nitzschia species present: May 17 (st. 3, 5 and 7), May 24 (st. 3 and 5), May 31 (st. 2 and 3), June 7 (st. 1 and 6), July 13 (st. 3), August 24 (st. 3), and September 13 (st. 2). High total abundances of Pseudo-nitzschia species were found in May-July 2005 (up to 4.6 x $10^{5}$ cells/l), August (up to $1.6 \times 10^{6}$ cells/l), September (up to $8.8 \times 10^{5}$ cells/l) and October (up to $7.1 \times 10^{5}$ cells/l) (Y.B. Okolodkov, unpubl. data). Starting from late October, the abundance drastically diminished, usually varying between $1.0 \times 10^{3}$ and $5.0 \times 10^{3}$ cells/l, and only once showed a high number of cells ( $8.9 \times 10^{4}$ cells/l at st. 1 , on November 15 , the highest abundance observed during the period from early October through mid-February).

DIC microscopy was used to determine the general groups of Pseudo-nitzschia present (e.g., P. multiseries/pungens, P. delicatissima complex, P. brasiliana/linea, 
Parsons et al.: Diversity and morphology of Pseudo-nitzschia of the Sistema Arrecifal Veracruzano

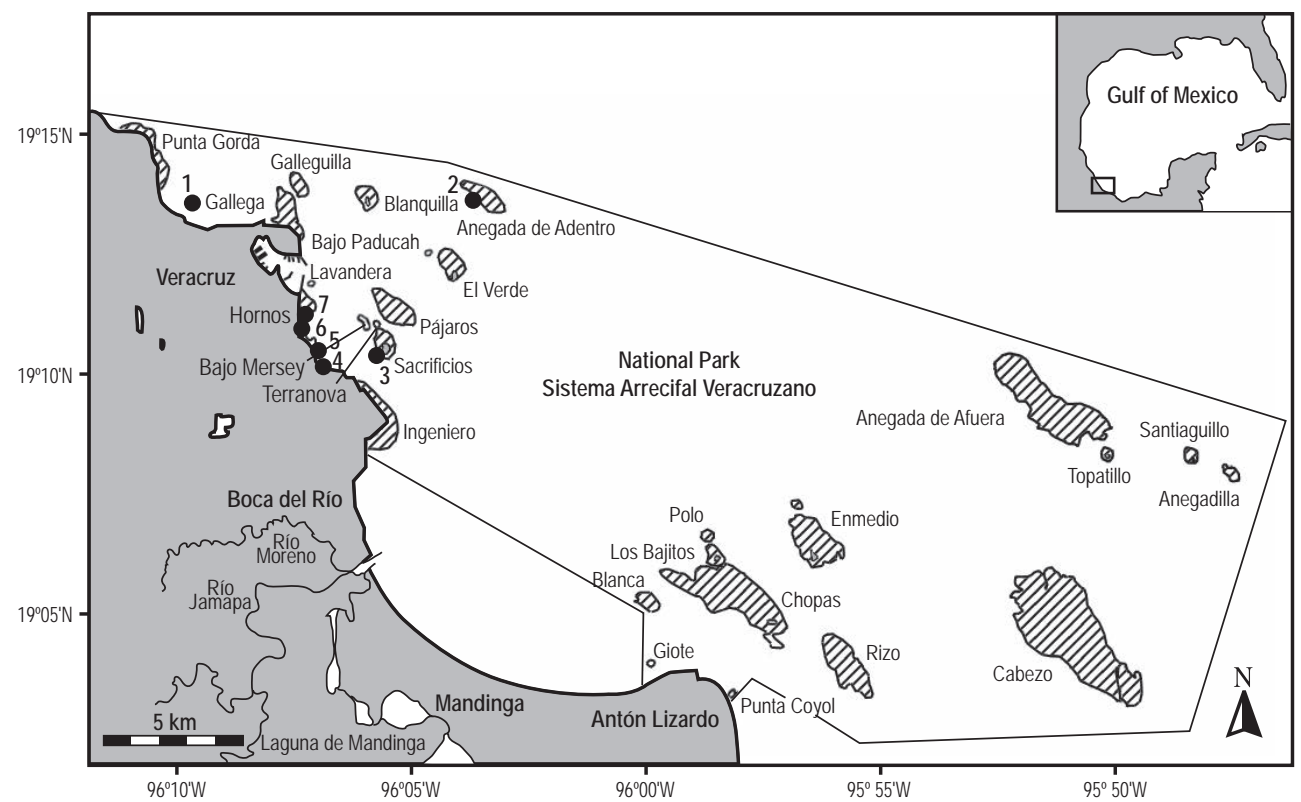

Fig. 1. Sampling sites (filled circles) in the National Park Sistema Arrecifal Veracruzano, Gulf of Mexico. Hatched areas are coral reefs.

and P. subfraudulenta/fraudulenta), which also facilitated EM analysis by providing some level of diversity to be expected. Valve lengths were also recorded during DIC examination. Cell length measurements made via DIC microscopy could not always be coupled with EM observations due to the inability to identify many species (i.e., the above groups) during light microscopy observation. For this reason, the data on the variability of the cell length for four species out of seven are absent. While scanning electron microscopy (SEM) was adequate for identifying most of the Pseudonitzschia species encountered, transmission electron microscopy (TEM) was needed to distinguish among the various species within the "pseudodelicatissima/cuspidata complex" where examination of the poroid hymen structure (Lundholm et al., 2003) was required.

Frustule samples for microscope analysis were processed according to Parsons et al. (1999). Samples were boiled in concentrated $\mathrm{HNO}_{3}$ for $20 \mathrm{~min}$, and then washed six times with distilled water. The frustules were then resuspended in $1 \mathrm{ml}$ of deionized, distilled water and transferred to a coverslip (DIC), stub (SEM) or grid (TEM) for examination. For DIC microscopic analysis, $0.2 \mathrm{ml}$ of suspension was transferred to a $25 \mathrm{~mm}$, No. 1 square coverslip (Fisher Scientific, 12-548C, Pitts- 
burgh, PA, USA), dried on a hot plate (Fisher Scientific Isotemp, Pittsburgh, PA, USA) at low setting, and permanently mounted in Naphrax (Northern Biological Supplies, Ipswich, UK). These prepared slides were then examined on an Olympus BX51 microscope fitted with DIC optics at 600x and 1000x magnification.

For SEM, $0.1 \mathrm{ml}$ of the suspension was transferred to a $15 \mathrm{~mm}$, round coverslip (Ted Pella, Inc., Prod. No. 26024, Redding, CA, USA), which was then affixed to a pin-style, 0.5” aluminum mount (Ted Pella, Inc., Prod. No. 16084-1, Redding, CA, USA) with PELCO $12 \mathrm{~mm}$ conductive, adhesive pads (Ted Pella, Inc., Prod. No. 16111, Redding, CA, USA). Stubs were air dried overnight and then sputter-coated using a Fullam EMS-76 prior to examination on a Hitachi 3400SN SEM at a working distance of $10 \mathrm{~mm}$ and a voltage of $25 \mathrm{kV}$. For TEM, $\sim 0.025 \mathrm{ml}$ of the suspension was transferred to a copper grid, size 300, and covered with carbon (Electron Microscopy Sciences, Hatfield, PA, USA) for observation in a JEOL JEM1400 TEM. All EM work was conducted at the Florida Fish and Wildlife Research Institute, St. Petersburg, Florida, USA.

The following morphometric measurements were made to assist in taxonomic determination (Table 1): cell length (DIC); valve width (SEM and TEM); number of fibulae and striae per $10 \mu \mathrm{m}$, number of rows of poroids in each stria (SEM and TEM); poroid number per $1 \mu \mathrm{m}$ (TEM); and the pattern of perforations in the hymen of each poroid (TEM). Additionally, the valve shape and the shape of its extremities (DIC and SEM) were considered.

\section{RESULTS}

Description of the genus

\section{Pseudo-nitzschia H. Peragallo in H. et M. Peragallo, 1900}

Type (lectotype): Pseudo-nitzschia seriata (Cleve) H. Peragallo in H. et M. Peragallo, 1900.

The following description is based on the diagnosis by Hasle (1993).

Species of Pseudo-nitzschia form chain colonies characterized by overlapped cells. Each cell contains two chloroplasts, each located closer to the extremities, and a central nucleus. Individual cells and colonies can move, gliding in the longitudinal direction. The cingulum consists of a series of linear bands. For identification, the cells should be examined in valve view. The frustules are usually linear or lanceolate 
in both valve and girdle view, but some species are asymmetric along the apical axis in valve view. The number of interstriae is equal or approximately double compared to the number of fibulae, and one or more rows of poroids between the striae are present. The raphe is eccentric and not elevated above the valvar surface, and the raphe wall lacks poroids. Two raphes of two adjacent cells are located one against other. Some species have a central nodule (= central interspace). Using the light microscope, it can be observed as a larger space between the central fibulae.

Hasle (1965) and Hasle \& Syvertsen (1996) divided Pseudo-nitzschia into two groups: the "seriata complex" (valve width $>3 \mu \mathrm{m}$ ) and the "delicatissima complex" $(<3 \mu \mathrm{m})$. Lundholm et al. $(2002,2003)$ further clarified two more groups (the "americana complex" and the "pseudodelicatissima/cuspidata complex"); the former is distinguished via light microscopy by its valves with rounded ends and shorter lengths $(<65 \mu \mathrm{m})$. The "pseudodelicatissima/cuspidata complex" is distinguished morphologically primarily by differences in the structure of the poroid hymens and girdle bands (Lundholm et al., 2003).

Table 1. Morphometric characteristics of Pseudo-nitzschia species found in the National Park Sistema Arrecifal Veracruzano.

\begin{tabular}{lccccc}
\hline Species & $\begin{array}{c}\text { Length } \\
(\mu \mathrm{m})\end{array}$ & $\begin{array}{c}\text { Width } \\
(\mu \mathrm{m})\end{array}$ & $\begin{array}{c}\text { Striae in } \\
10 \mu \mathrm{m}\end{array}$ & $\begin{array}{c}\text { Fibulae in } \\
10 \mu \mathrm{m}\end{array}$ & $\begin{array}{c}\text { Poroids in } \\
1 \mu \mathrm{m}\end{array}$ \\
\hline P. brasiliana & $23-40$ & $2.0-2.7$ & $24-25$ & $22-24$ & $9.0-9.5$ \\
"delicatissima" complex ${ }^{1}$ & $40-85$ & & & & \\
P. calliantha & & $1.4-1.6$ & $33-40$ & $15-22$ & $4.1-6.5^{\mathrm{H}}$ \\
P. cuspidata & & $1.5-1.7$ & $36-41$ & $19-23$ & $6.0-6.8^{\mathrm{HH}}$ \\
P. delicatissima & & $1.3-1.4$ & $33-36$ & $21-24$ & $9.1-11.4$ \\
P. pseudodelicatissima & & $1.1-1.6$ & $35-44$ & $17^{\mathrm{L}}-23$ & $5.0-7.0$ \\
P. pungens & $93-126$ & $2.8-3.2$ & $11-14$ & $11-15$ & $3.0-3.4$ \\
P. cf. subcurvata & $28-36$ & $1.9-2.5$ & & & \\
\hline
\end{tabular}

${ }^{1}$ Measurements of the cell length for the four species of the "delicatissima complex" listed below are given for all of them considering impossible to distinguish between them in light microscope.

${ }^{\mathrm{H}}$ Upper end of measurements is higher than those in literature (Lundholm et al., 2003).

${ }^{\mathrm{HH}}$ Upper end of measurements is higher than those in literature (Hasle, 1965; Skov et al., 1999; Lundholm et al., 2003).

${ }^{\mathrm{L}}$ Lower end of measurements is lower than those in literature (Lundholm et al., 2003, 2006). 
Description of species

1. Pseudo-nitzschia brasiliana Lundholm, Hasle et G. A. Fryxell, 2002 (Pl. 1, Fig. 1; Pl. 2, Fig. 1)

Cells are narrow, linear, with widely rounded extremities, 23-40 $\mu \mathrm{m}$ long, 2.0-2.7 $\mu \mathrm{m}$ wide, overlapped 1/8-1/11 of the cell length. 22-24 striae in $10 \mu \mathrm{m}$ and 24-25 fibulae in $10 \mu \mathrm{m}$ (Table 1). Two rows of poroids more or less circular, 9.0-9.5 in $1 \mu \mathrm{m}$, tending to form the third row near the valve margins. Central interspace is absent.

Taxonomic note. This species belongs to the "americana complex". Unlike the "seriata complex", the species of the "americana complex" have rounded valvar poles, slightly shorter cells, and weaker silicification. Unlike the "delicatissima complex", the valves are wider and more robust. The number of fibulae and striae in the specimens from NPSAV is within that reported by other authors (1928 fibulae and striae in $10 \mu \mathrm{m}$ in Lundholm et al., 2002, and Quijano-Scheggia et al., 2008, 2011).

A new record for the SW Gulf of Mexico.

Toxicity. The species has not yet been reported to be toxic (Lundholm et al., 2002).

2. Pseudo-nitzschia calliantha Lundholm, Moestrup et Hasle, 2003 (Pl. 1, Fig. 2)

Cells are very narrow, linear, 40-85 $\mu \mathrm{m}$ long, 1.4-1.6 $\mu$ m wide. The degree of overlap between cells in colonies is unknown (it is not given in the original description by Lundholm et al., 2003). 33-40 striae in $10 \mu \mathrm{m}$ and 15-22 fibulae in 10 $\mu \mathrm{m}$. One row of relatively large circular poroids, 4.1-6.5 in $1 \mu \mathrm{m}$. The hymen is discontinuously perforated, consisting of 4-9 peripheral sectors and a central area; the poroids having the lower number of sectors are always closer to the valve opposite to that with smaller fibulae and poroids. Central interspace is present.

Taxonomic note. This species belongs to the "delicatissima complex" (Hasle \& Syvertsen, 1996) and the "pseudodelicatissima/cuspidata complex" (Lundholm et al., 2003). The numbers of fibulae and striae in the specimens from NPSAV are within those reported by others (19-20 and 39-40 in $10 \mu \mathrm{m}$, respectively, in Bargu et al., 2004; 15-22 and 34-39 in $10 \mu \mathrm{m}$ in Lundholm et al., 2003; 15-26 and 30-40 in 10 $\mu \mathrm{m}$ in Quijano-Scheggia et al., 2008). 
A new record for the SW Gulf of Mexico. It was identified for the first time in the Gulf of Mexico in Florida (Lundholm et al., 2003). Recently, it was reported in Louisiana waters, where it was dominant among other Pseudo-nitzschia species (Del Rio et al., 2010).

Toxicity. Some strains of this species are toxic (Lundholm et al., 1997, 2003; Bates \& Trainer, 2006). However, Orlova et al. (2008) did not detect any toxicity in a strain of $P$. calliantha from the Sea of Japan, and strains from the southern Gulf of St. Lawrence, Canada, were also below the limit of detection for DA (S. Bates, pers. comm.).

\section{Pseudo-nitzschia cuspidata (Hasle) Hasle, 1974 emend. Lundholm, Moestrup et Hasle, 2003 (Pl. 1, Fig. 3)}

Bas.: Nitzschia cuspidata Hasle, 1965.

Cells are very narrow, linear or lanceolate, with acute extremities, 1.5-1.7 $\mu \mathrm{m}$ wide, overlapped 1/5-1/6 of the cell length. 36-41 striae in $10 \mu \mathrm{m}$ and 19-23 fibulae in $10 \mu \mathrm{m}$. One row of relatively large poroids, $6.0-6.8$ in $1 \mu \mathrm{m}$. The hymen is usually perforated by four sectors (each partially divided), so that the perforation is not continuous. Central interspace is present.

Taxonomic note. This species belongs to the "delicatissima complex" (Hasle \& Syvertsen, 1996) and the "pseudodelicatissima/cuspidata complex" (Pl. 2, Fig. 2-4; Lundholm et al., 2003). The number of fibulae and striae in the specimens from NPSAV are within those reported by others, however, the poroids are somewhat denser (14-22 and 29-39 in $10 \mu \mathrm{m}$ and 4-6 poroids in $1 \mu \mathrm{m}$, respectively, in Hasle, 1965, and Skov et al., 1999; 19-25 and 35-44 in $10 \mu \mathrm{m}$ and 4-6 poroids in $1 \mu \mathrm{m}$ in Lundholm et al., 2003). The hymen in P. cuspidata and P. pseudodelicatissima is very similar, so that it is not always possible to distinguish between these two species even in TEM; principally, they are distinguished by the shape of the valves (tapering from the middle part of the valve towards the extremities in P. cuspidata and tapering only near the extremities in P. pseudodelicatissima) and by the cell width (relatively thinner in P. pseudodelicatissima) (Lundholm et al., 2003).

In the SW Gulf of Mexico, the species has been previously reported from Tuxpan, Veracruz, México (Lundholm et al., 2003).

Toxicity. Reports prior to 2003 about the toxicity of P. cuspidata are not reliable due to confusion of this species with $P$. pseudodelicatissima (Lundholm et al., 2003). However, more recent studies have confirmed the toxicity of $P$. cuspidata (Trainer et al., 2009). 
4. Pseudo-nitzschia delicatissima (Cleve) Heiden, 1928 (Pl. 1, Fig. 4)

Bas.: Nitzschia delicatissima Cleve, 1897.

Syn.: Nitzschia actydrophila Hasle, 1965.

Cells are very narrow, linear or lanceolate, 40-85 $\mu \mathrm{m}$ long, 1.3-1.4 $\mu \mathrm{m}$ wide, overlapped $1 / 7-1 / 10$ of the cell length. 33-36 striae in $10 \mu \mathrm{m}$ and 21-24 fibulae in 10 $\mu \mathrm{m}$. Two rows of small poroids. The hymen has a continuously perforated area, 9.111.4 poroids in $1 \mu \mathrm{m}$. Central interspace is present.

Taxonomic note. This species belongs to the "delicatissima complex" (Hasle \& Syvertsen, 1996). The number of fibulae in the specimens from NPSAV is within that reported by Hasle (1965), i.e., 19-25 in $10 \mu \mathrm{m}$.

Toxicity. This species has never caused any natural toxic event (Skov et al., 1999). However, the presence of the DA was registered in cultures (Smith et al., 1991; Rhodes et al., 1998). DA is reported as undetectable in most culture studies on P. delicatissima (Villac et al., 1993; Lundholm et al., 1994; Fehling et al., 2005).

\section{Pseudo-nitzschia pseudodelicatissima (Hasle) Hasle, 1993 emend. Lundholm, Moestrup et Hasle, 2003 (Pl. 1, Fig. 5)}

Bas.: Nitzschia pseudodelicatissima Hasle, 1976.

Syn.: Nitzschia delicatula Hasle, 1965.

Cells are very narrow, linear, 40-85 $\mu \mathrm{m}$ long, 1.1-1.6 $\mu \mathrm{m}$ wide, symmetric in relation to the apical axis, with more or less acute extremities, overlapped 1/5-1/6 of the cell length. 35-44 striae in $10 \mu \mathrm{m}$ and 17-23 fibulae in $10 \mu \mathrm{m}$. One row of small, circular, ovoid or more or less quadrate poroids with rounded angles, 5.0-7.0 in $1 \mu \mathrm{m}$. The hymen has 1 to 4 perforated areas (partially divided), so that the perforation is not continuous. Central interspace is present.

Taxonomic note. This species belongs to the "delicatissima complex". The number of poroids in the specimens from NPSAV is slightly higher compared to those reported by others (4-6 in $1 \mu \mathrm{m}$ in Hasle, 1965; 5-6 in Takano \& Kuroki, 1977, and Rivera, 1985; 4.8-5.5 in Lundholm et al., 2003). Also, the number of striae and fibulae are higher (29-33 and 16-19 in $10 \mu \mathrm{m}$, respectively, in Licea, 1992).

Toxicity. Certain strains of this species are toxic (Pan et al., 2001 [now known to be P. pseudodelicatissima instead of P. sp. cf. pseudodelicatissima, M. Parsons pers. obs.]; Bates \& Trainer, 2006; Moschandreou et al., 2010), although more often non-toxic strains have been reported (see references in Moschandreou et al., 2010). 


\section{Pseudo-nitzschia pungens (Grunow ex Cleve) Hasle, 1993 (Pl. 1, Fig. 6)}

Bas.: Nitzschia pungens Grunow ex Cleve, 1897.

Cells linear or lanceolate, symmetrical in relation to the apical axis, 93-126 $\mu \mathrm{m}$ long, 2.8-3.2 $\mu \mathrm{m}$ wide, overlapped 1/3-1/4 of the cell length. 11-14 striae in $10 \mu \mathrm{m}$ and 11-15 fibulae in $10 \mu \mathrm{m}$. Two rows of large, circular poroids, 3.0-3.4 in $1 \mu \mathrm{m}$.
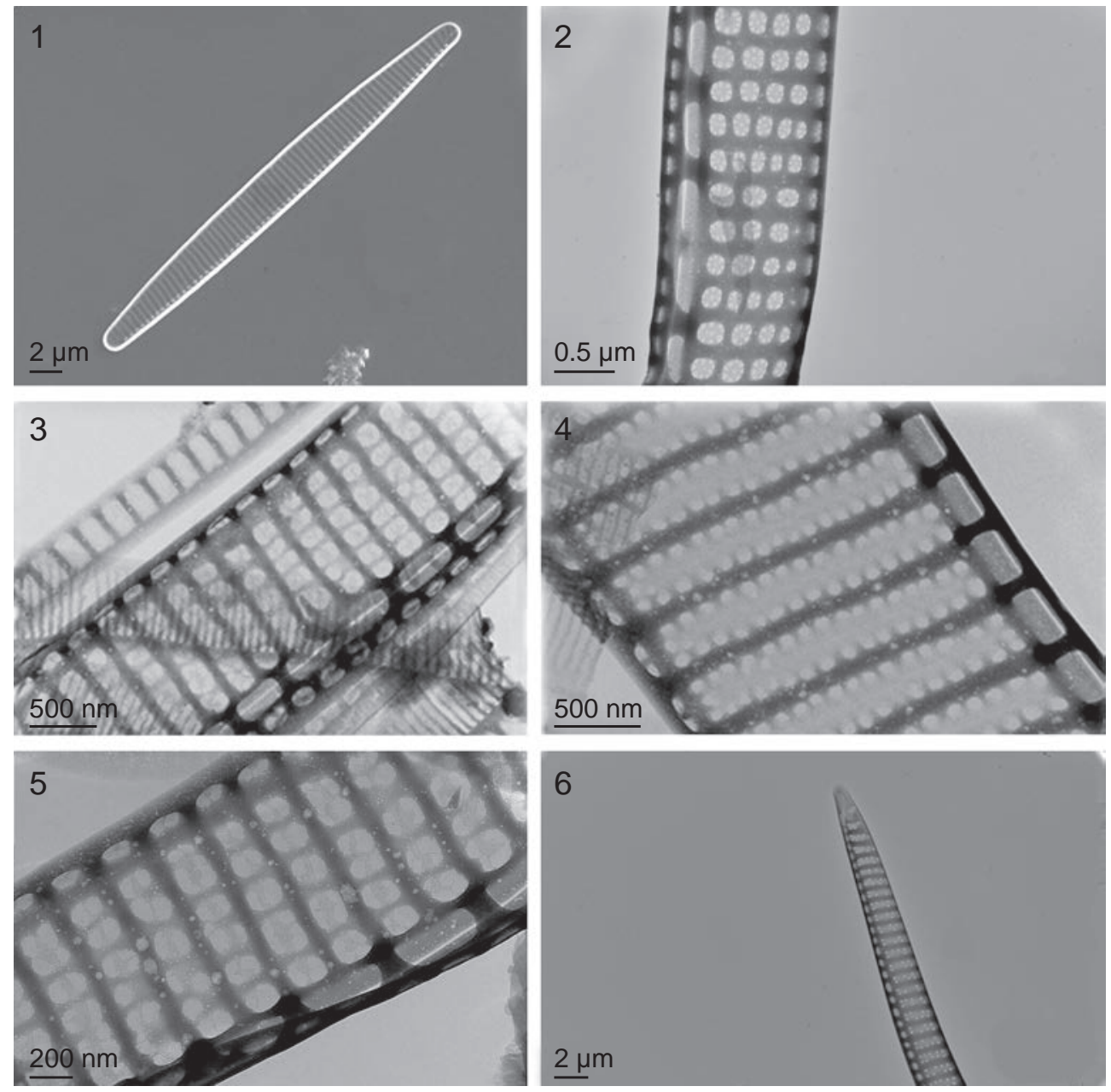

Plate 1. Morphology of Pseudo-nitzschia species from the National Park Sistema Arrecifal Veracruzano in electron microscope (1-SEM, 2-6-TEM): $1-P$. brasiliana, 2-P. calliantha, 3 - P. cuspidata, 4 - P. delicatissima, 5 - P. pseudodelicatissima, 6 - P. pungens. 

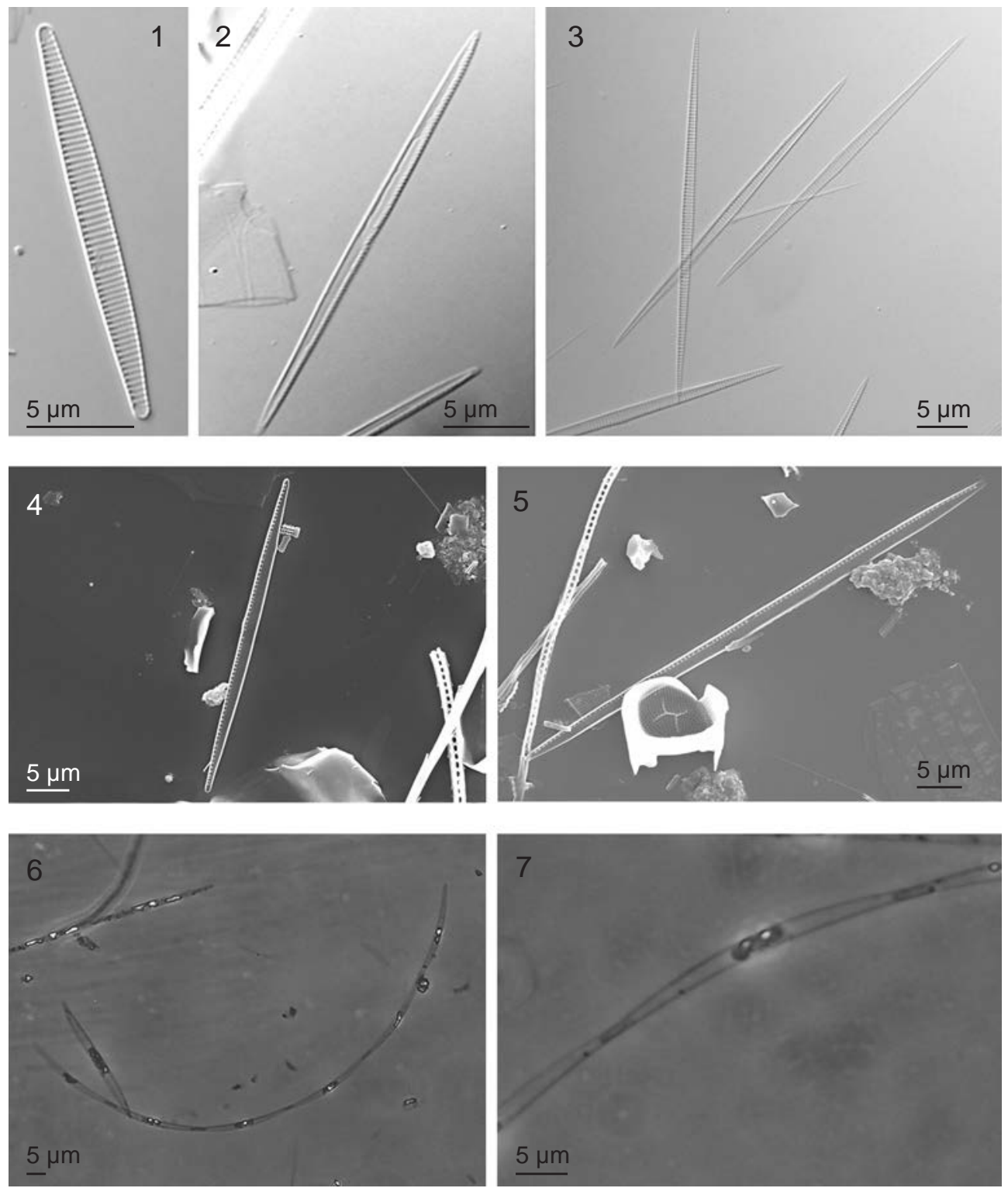

Plate 2. Morphology of Pseudo-nitzschia species from the National Park Sistema Arrecifal Veracruzano: 1 (DIC) - P. brasiliana; 2 and 3 (DIC), 4 and 5 (SEM) - P. "pseudodelicatissima/ cuspidata complex"; 6 and 7 (phase contrast) - P. cf. subcurvata. 
Taxonomic note. This species belongs to the "seriata complex" (Hasle \& Syvertsen, 1996). The number of poroids in the specimens from NPSAV is higher than that reported in Quijano-Scheggia et al. (2008) (2.5-3.0 in $1 \mu \mathrm{m}$ ), but is within the range reported by others (3-4 in $1 \mu \mathrm{m}$ in Hasle, 1965; Takano \& Kuroki, 1977; Rivera, 1985). The literature sometimes indicates one or three rows of poroids in $1 \mu \mathrm{m}$ (Hasle, 1965; Rivera, 1985), whereas only two rows were observed in the cells from NPSAV.

Toxicity. The species is most often characterized as being non-toxic; however, some strains do produce low amounts of DA (Bates \& Trainer, 2006). DA was detected in strains isolated from Washington State, USA (Trainer et al., 1998; Baugh et al., 2006) and New Zealand (Rhodes et al., 1998).

7. Pseudo-nitzschia cf. subcurvata (Hasle) G. A. Fryxell, 1993 (Pl. 2, Fig. 6 and 7) Bas.: Nitzschia subcurvata Hasle, 1964.

Cells are lanceolate, curved in relation to the apical axis: in valve view, convex from one side and concave from another, 28-36 $\mu \mathrm{m}$ long, 1.9-2.5 $\mu \mathrm{m}$ wide, overlapped 1/7-1/8 of the cell length. Striae and fibulae were not distinguished in the light microscope. Cells are solitary or form colonies of 3 to 6 cells.

Taxonomic note. This species belongs to the "delicatissima complex". The cells previously observed by others are 47-113 $\mu \mathrm{m}$ long, 1.5-2.5 $\mu \mathrm{m}$ wide, have 44-49 striae and 12-18 fibulae in $10 \mu \mathrm{m}$ (Hasle, 1964; Hasle \& Syvertsen, 1996).

Biogeographic note. Pseudo-nitzschia subcurvata is abundant in the Antarctic (Hasle, 1964; Hasle \& Syvertsen, 1996; Scott \& Thomas, 2005; Almandoz et al., 2008). The species has been also encountered in the Arctic, Subarctic Pacific and near the eastern Australia (Taylor \& Waters, 1982; Crosbie \& Furnas, 2001; Flint et al., 2001; Ikävalko, 2003). The species was first reported for the Gulf of Mexico by Aké-Castillo \& Okolodkov (2009).

Toxicity. There are no reports about the toxicity of this species.

\section{DISCUSSION}

Out of seven species presented in this work, Pseudo-nitzschia brasiliana and $P$. calliantha are new records for the SW Gulf of Mexico. Pseudo-nitzschia multiseries, $P$. pungens, $P$. subfraudulenta and $P$. subpacifica have been previously reported from the Strait of Yucatan (Licea, 1992), and P. delicatissima from Veracruz (Santoyo \& Signoret, 1988). A similar diversity of Pseudo-nitzschia was noted by Parsons et al. 
(1998), who reported on the presence of six species of Pseudo-nitzschia in the northern Gulf of Mexico: P. cf. americana (now known to be P. brasiliana), P. delicatissima, $P$. pseudodelicatissima (now known to also include $P$. calliantha and $P$. cuspidata), $P$. multiseries, $P$. pungens and $P$. subfraudulenta. $P$. multistriata has also been observed in the northern Gulf of Mexico (M. Parsons, pers. obs.). Three of the species found in the northern Gulf of Mexico were not observed in this study: P. multiseries, $P$. multistriata and $P$. subfraudulenta, suggesting that there may be a greater diversity of Pseudo-nitzschia present in the NPSAV than captured in this study, or that biogeographic limits of these species may be present. Similarly, $P$. subcurvata was not observed in the northern Gulf of Mexico, possibly due to similar reasons. Wolny \& Heil (2005, unpubl. data) reported on the presence of nine species of Pseudo-nitzschia in coastal waters of west Florida (P. calliantha, P. cuspidata, P. delicatissima, P. granii, $P$. heimii, $P$. multiseries, $P$. pseudodelicatissima, $P$. pungens and $P$. turgidula), again demonstrating the presence of additional species (P. granii, $P$. heimii and $P$. turgidula) and the absence of others ( $P$. multistriata, $P$. subcurvata and $P$. subfraudulenta). It is therefore likely that a higher diversity of Pseudo-nitzschia is present in the Gulf of Mexico than has been documented to date, and/or that biogeographic limitations may be present for some species in some localities; e.g., P. multiseries was absent in samples $>27^{\circ} \mathrm{C}$ in coastal Louisiana (M. Parsons, unpubl. data).

The analysis of our samples showed the frequent dominance of Pseudonitzschia species in net plankton. Pseudo-nitzschia delicatissima was one of the three most conspicuous diatoms in the annual cycle of 1975-1976 at Punta Limón, in the central part of coast of the State of Veracruz (Santoyo \& Signoret, 1988). Pseudo-nitzschia species continued to be a dominant member of the phytoplankton community, dominating the phytoplankton community in NPSAV from May into November 2005, reaching bloom concentrations $\left(1.5\right.$ x $10^{6}$ cells/l) in August 2005 (Okolodkov et al., 2009). This time period was characterized by higher temperature (up to $32{ }^{\circ} \mathrm{C}$ ) and high precipitation (Okolodkov et al., 2009), suggesting possible nutrient enrichment related to local riverine inputs from the rivers Jamapa (discharging into the NPSAV), La Antigua (to the north-west), and Papaloapan (to the south-east). Just as other studies have demonstrated that Pseudonitzschia can proliferate in eutrophic conditions (e.g., Dortch et al., 1997; Parsons et al., 2002), continued nutrient enrichment and subsequent eutrophication of the coastal urban zone of Veracruz-Boca del Río-Antón Lizardo from these riverine inputs could result in larger and more frequent Pseudo-nitzschia blooms. This study demonstrates that potentially toxic Pseudo-nitzschia species are present in NPSAV; thus their increased abundances could lead to an increased risk of ASP 
in the study area. The vectors of DA in the NPSAV are still unknown, however, and will require further study. Seasonality of individual Pseudo-nitzschia species and their relationships with physical-chemical variables in the context of the entire planktonic phytocoenosis must be one of the future priorities to allow evaluation of the potential risk of ASP in the study area.

\section{ACKNOWLEDGMENTS}

We thank the Aquarium of Veracruz, Guadalupe Campos-Bautista (responsible for the project "Monitoreo de florecimientos algales nocivos en el área del Acuario de Veracruz en mayo del 2005-mayo del 2006”) for logistics during sampling, and the Dirección General de Investigaciones, Universidad Veracruzana, for financial support for the project "Algas de la zona arrecifal Veracruzana, Golfo de México, con énfasis en las algas rojas, diatomeas y dinoflagelados" (2007-2009), awarded to YBO. We also thank Cindy Heil for her permission to use the electron microscopes at the Florida Fish and Wildlife Research Institute (FWRI) in St. Petersburg, Florida, USA, and Paula Scott (FWRI) for her assistance in sample preparation and examination on the microscopes. Stephen Bates (Fisheries and Oceans Canada, Moncton, New Brunswick, Canada) reviewed the manuscript and offered valuable suggestions. Néstor M. Ruíz-Robinson and Natalia Okolodkova are thanked for technical assistance in constructing the photographic plates, and Marcia M. Gowing for help with revising the manuscript.

\section{LITERATURE CITED}

Akallal, R. \& A. Mouradi. 2000. Pseudo-nitzschia pseudodelicatissima bloom in Atlantic Moroccan waters 1999. Harmful Algae News 20: 14.

Aké-Castillo,J. A.\&Y.B. Okolodkov. 2009.Pseudo-nitzschia subcurvata (Bacillariophyceae) in the Gulf of Mexico? Harmful Algae News 40: 6-7.

Almandoz, G. O., M. E. Ferrario, G. A. Ferreyra, I. R. Schloss, J. L. Esteves \& F. E. Paparazzo. 2007. The genus Pseudo-nitzschia (Bacillariophyceae) in continental shelf waters of Argentina (Southwestern Atlantic Ocean, 38-55²). Harmful Algae 6: 93-103.

Almandoz, G., G. A. Ferreyra, I. R. Schloss, A. I. Dogliotti, V. Rupolo, F. E. Paparazzo, J. L. Esteves \& M. E. Ferrario. 2008. Distribution and ecology of Pseudo-nitzschia species (Bacillariophyceae) in surface waters of the Weddell Sea (Antarctica). Polar Biol. 6: 429-442. 
Badylak, S., E. Phlips \& K. Kelley. 2006. Pseudo-nitzschia calliantha (Bacillariophyceae) from the Indian River Lagoon, Florida. Diatom Res. 21(2): 263-267.

Bargu, S., T. Koray \& N. Lundholm. 2004. First report of Pseudo-nitzschia calliantha Lundholm, Moestrup \& Hasle 2003, a new potentially toxic species from Turkish coasts. E. U. J. Fish. Aquat. Sci. 19(3-4): 479-483.

Bates, S. S., C. J. Bird, A. S. W. de Freitas, R. Foxall, M. Gilgan, L. A. Hanic, G. R. Johnson, A. W. McCulloch, P. Odense, R. Pocklington, M. A. Quilliam, P. G. Sim \& J. C. Smith. 1989. Pennate diatom Nitzschia pungens as the primary source of domoic acid, a toxin in shellfish from eastern Prince Edward Island, Canada. Can. J. Fish. Aquat. Sci. 46: 1203-1215.

Bates, S. S. \& D. J. A. Richard. 2000. Shellfish harvest area closure due to domoic acid - Mill River, Prince Edward Island. Harmful Algae News 21: 6-7.

Bates, S. S. \& V. L. Trainer. 2006. The ecology of harmful diatoms. In: Granéli, E. \& J. T. Turner (eds.). Ecology of harmful algae. Ecological Studies 189. Springer-Verlag. Berlin. pp. 81-93.

Baugh, K. A., J. M. Bush, B. D. Bill, K. A. Lefebvre \& V. L. Trainer. 2006. Estimates of specific toxicity in several Pseudo-nitzschia species from the Washington coast, based on culture and field studies. Afr. J. Mar. Sci. 28: 393-397.

Bogan, Y. M., K. Bender, A. Hervas, D. J. Kennedy, J. W. Slater \& P. Hess. 2007. Spatial variability of domoic acid concentration in king scallops Pecten maximus off the southeast coast of Ireland. Harmful Algae 6: 1-14.

Cho, E. S., H. G. Hur, H. S. Byun, S. G. Lee, L. L. Rhodes, C. S. Jeong \& J. G. Park. 2002. Monthly monitoring of domoic acid producer Pseudo-nitzschia multiseries (Hasle) Hasle using species-specific DNA probes and WGA lectins and abundances of Pseudo-nitzschia species (Bacillariophyceae) from Chinhae Bay, Korea. Bot. Mar. 45: 364-372.

Conger, P. S., G. A. Fryxell \& S. Z. El-Sayed. 1972. Diatom species reported from the Gulf of Mexico. In: El-Sayed, S. Z., W. M. Sackett, L. M. Jeffrey, A. D. Fredericks, R. P. Saunders, P. S. Conger, G. A. Fryxell, K. A. Steidinger \& S. A. Earle (eds.). Chemistry, primary productivity, and benthic algae of the Gulf of Mexico. Folio of the Serial Atlas of the Marine Environment. Office of Naval Research, Texas A\&M Research Foundation, College of Geosciences, Texas A\&M University. College Station, Texas. pp. 18-23.

Cortés-Altamirano, R. \& A. P. Sierra-Beltrán. 2008. Biotoxins from freshwater and marine harmful algal blooms occurring in Mexico. Toxin Rev. 27: 27-77.

Crosbie, N. D. \& M. J. Furnas. 2001. Net growth rates of picocyanobacteria and nano-/ microphytoplankton inhabiting shelf waters of the central $\left(17^{\circ} \mathrm{S}\right)$ and southern $\left(20^{\circ} \mathrm{S}\right)$ Great Barrier Reef. Aquat. Microb. Ecol. 24: 209-224.

Del Rio, R., S. Bargu, D. Baltz, S. Fire, G. Peterson \& Z. Wang. 2010. Gulf menhaden (Brevoortia patronus): a potential vector of domoic acid in coastal Louisiana food webs. Harmful Algae 10: 19-29.

Dortch, Q., R. Robichaux, S. Pool, D. Milsted, G. Mire, N. N. Rabalais, T. M. Soniat, G. A. Fryxell, R. E. Turner \& M. L. Parsons. 1997. Abundance and vertical flux of Pseudonitzschia in the northern Gulf of Mexico. Mar. Ecol. Prog. Ser. 146: 249-264. 
Fehling, J., D. H. Green, K. Davidson, C. J. Bolch \& S. S. Bates. 2004. Domoic acid production by Pseudo-nitzschia seriata (Bacillariophyceae) in Scottish waters. J. Phycol. 40: 622-630.

Fehling, J., K. Davidson \& S. S. Bates. 2005. Growth dynamics of non-toxic Pseudo-nitzschia delicatissima and toxic $P$. seriata (Bacillariophyceae) under simulated spring and summer photoperiods. Harmful Algae 4: 763-769.

Flint, M. V., I. N. Sukhanova, A. I. Kopylov, S. G. Poyarkov \& T. E. Whitledge. 2001. Plankton distributions associated with frontal zones in the vicinity of the Pribylof Islands. Deep-Sea Res. II 49: 6069-6093.

Fryxell, G. A., M. E. Reap \& D. L. Valencic. 1990. Nitzschia pungens Grunow f. multiseries Hasle: observations of a known neurotoxic diatom. Beih. Nova Hedw. 100: 171-188.

Fryxell, G. A., M. E. Reap, D. L. Roelke, L. A. Cifuentes \& D. L. Valencic. 1991. Confirmed presence of neurotoxin-producing diatom around Galveston, Texas. In: Shipley, F. S. \& R. W. Kiesling (eds.). Proceedings of the Galveston Bay Characterization Workshop, February 21-23, 1991. The Galveston Bay National Estuary Program. Publication GBNEP-6. Webster, Texas. pp. 153-154.

Gómez-Aguirre, S., S. Licea \& S. Gómez. 2004. Proliferaciones de Pseudo-nitzschia spp. (Bacillariophyceae) y otras especies del microplancton en la Bahía de Mazatlán, México. In: Sierra-Beltrán, A. P., R. Cortés-Altamirano, A. La Barbera Martínez \& F. Gavidia-Medina (eds.). Harmful algal blooms in the Caribbean. Rev. Biol. Trop. 52(1): 69-76.

Guiry, M. D. 2011. AlgaeBase. World-wide electronic publication. National University of Ireland, Galway. http://www.algaebase.org; searched on 05 May 2011.

Hasle, G. R. 1964. Nitzschia and Fragilariopsis species studied in the light and electron microscopes. I. Some marine species of the groups Nitzschiella and Lanceolatae. Skrift. Norske Vidensk. Akad. 16: 1-48.

Hasle, G. R. 1965. Nitzschia and Fragilariopsis species studied in the light and electron microscopes. II. The group Pseudo-nitzschia. Det Norske Videnskaps-Akademi i Oslo, I. Mat. Naturv. Klasse, Ny Serie. 18: 1-45.

Hasle, G. R. 1993. Nomenclatural notes on marine planktonic diatoms. The family Bacillariaceae. Beih. Nova Hedw. 106: 315-321.

Hasle, G. R. 2002. Are most of the domoic acid producing species of the diatom genus Pseudo-nitzschia cosmopolites? Harmful Algae 1: 137-147.

Hasle, G. R. \& E. E. Syvertsen. 1996. Marine diatoms. In: Tomas, C. R. (ed.). Identifying marine phytoplankton. Academic Press. San Diego, California. pp. 5-385.

Ikävalko, I. 2003. Report on sea ice communities (D 4.2.3.1). GROWTH Project GRD22000-30112 “ARCOP”. Finish Institute of Marine Research (Helsinki), Finland. 42 pp. (not paginated).

Kotaki, Y. K. Koike, M. Yoshida, C. Van Thuoc, N. T. Minh, N. C. Hoi, Y. Fukuyo \& M. Kodama. 2000. Domoic acid production in Nitzschia sp. (Bacillariophyceae) isolated from a shrimp culture pond in Do Son, Vietnam. J. Phycol. 36: 1057-1060.

Krayevsky, D. M., E. Meave del Castillo, E. Zamudio, J. N. Norris \& S. Frederique. 2009. Diatoms (Bacillariophyta) of the Gulf of Mexico. In: Felder, D. L. \& D. K. Camp. Gulf of Mexico origin, waters, and biota. Vol. 1, Biodiversity. Texas A\&M University Press. College Station, Texas. pp. 155-186. 
Licea, S. 1992. Especies de diatomeas seleccionadas del sur del Golfo de México, estudiadas en microscopio de luz y electrónico. Tesis de doctorado. Instituto de Ciencias del Mar y Limnología, Colegio de Ciencias y Humanidades, Universidad Nacional Autónoma de México. México, D.F. 66 pp., 30 lám.

Licea, S., Gómez-Aguirre, S. \& J. L. Moreno. 2000. The occurrence of the diatom genus Pseudo-nitzschia Peragallo in Mexican coastal waters, 1979-2000. In: EconomouAmmilli, A. (ed.). Proceedings of the 16th International Diatoms Symposium, Athens \& Aegean Islands. 25 August - 1 September, 2000. Amvrosiou Press, University of Athens. Athens, Greece. p. 78.

Licea, S., M. Ferrario \& S. Gómez-Aguirre. 2004. The occurrence and abundance of the diatom genus Pseudo-nitzschia Peragallo in the Mexican Waters (1979-2004). In: Pitcher, G. (ed.). Book of abstracts, XI International Conference on Harmful Algal Blooms. Cape Town, South Africa. 14-19 November. p. 169.

Liefer, J. D., H. L. MacIntyre, L. Novoveska, W. L. Smith \& C. P. Dorsey. 2009. Temporal and spatial variability in Pseudo-nitzschia spp. in Alabama coastal waters: A "hot spot” linked to submarine groundwater discharge? Harmful Algae 8: 706-714.

Lundholm, N. \& Ø. Moestrup. 2002. The marine diatom Pseudo-nitzschia galaxiae sp. nov. (Bacillariophyceae): morphology and phylogenetic relationships. Phycologia 41: 594605.

Lundholm, N., J. Skov, R. Pocklington \& Ø. Moestrup 1994. Domoic acid, the toxic amino acid and responsible for amnesic shellfish poisoning, now in Pseudonitzschia seriata (Bacillariophyceae) in Europe. Phycologia 33: 457-478.

Lundholm, N., J. Skov, R. Pocklington \& Ø. Moestrup 1997. Studies of the marine planktonic diatom Pseudo-nitzschia. 2. Autecology of P. pseudodelicatissima based on isolates from Danish coastal waters. Phycologia 36: 381-388.

Lundholm, N., G. R. Hasle, G. A. Fryxell \& P. E. Hargraves. 2002. Morphology, phylogeny and taxonomy of species within the Pseudo-nitzschia americana complex (Bacillariophyceae) with descriptions of two new species Pseudo-nitzschia brasiliana and Pseudo-nitzschia linea. Phycologia 41(5): 480-497.

Lundholm, N., Ø. Moestrup, G. R. Hasle \& K. Hoef-Emden. 2003. A study of the Pseudonitzschia pseudodelicatissima/cuspidata complex (Bacillariophyceae): what is $P$. pseudodelicatissima? J. Phycol. 39: 797-813.

Lundholm, N., P. Andersen, K. Jørgensen, B. Ring Thorbjørnsen, A. Cembella \& B. Krock. 2005. Domoic acid in Danish blue mussels due to a bloom of Pseudo-nitzschia seriata. Harmful Algae News 29: 8-10.

Lundholm, N., Ø. Moestrup, Y. Kotaki, K. Hoef-Emden, C. Scholin \& P. Miller. 2006. Inter- and intraspecific variation of the Pseudo-nitzschia delicatissima complex (Bacillariophyceae) illustrated by rRNA probes, morphological data and phylogenetic analyses. J. Phycol. 42: 464-481.

MacIntyre, H. L., A. L. Stutes, W. L. Smith, C. P. Dorsey, A. Abraham \& R.W. Dickey. 2011. Environmental correlates of community composition and toxicity during a bloom of Pseudo-nitzschia spp. in the northern Gulf of Mexico. J. Plankton Res. 33: 273-295. 
Meave del Castillo, M. E., J. A. Aké-Castillo \& S. L. Guerra-Martínez. 2000. Dominancia de las diatomeas del género Pseudo-nitzschia H. Peragallo en las costas de Baja California (Marzo 1999). In: Book of abstracts, XII National Congress of Oceanography (22-26 May). Huatulco, Oaxaca, México. p. 145.

Meave del Castillo, M. E. \& D. U. Hernández-Becerril. 1998. Fitoplancton. In: TapiaGarcía, M. (ed.). El Golfo de Tehuantepec: el ecosistema y sus recursos. Universidad Autónoma Metropolitana-Iztapalapa. México, D.F. pp. 59-74.

Moreno-Ruiz, J. L., S. Licea, M. Tapia-García, C. González-Macias, J. M. FernándezGonzáñez \& G. Figueroa-Torres. 2004. Some harmful and toxic diatom blooms in the southern Mexican Pacific (May 1990-Dec. 2001). In: Steidinger, K. A., J. H. Landsberg, C. R. Tomas \& G. A. Vargo (eds.). Harmful Algae 2002. Book of abstracts of the Xth International Conference on Harmful Algae, October 21-25, 2002. St. Pete Beach, Florida, USA. Florida Fish and Wildlife Conservation Commission, Florida Institute of Oceanography and Intergovernmental Oceanographic Commission of UNESCO. St. Petersburg, Florida. p. 205.

Moschandreou, K. K., D. Papaefthimiou, P. Katikou, E. Kalopesa, A. Panou \& G. Nikolaidis. 2010. Morphology, phylogeny and toxin analysis of Pseudo-nitzschia pseudodelicatissima (Bacillariophyceae) isolated from the Thermaikos Gulf, Greece. Phycologia 49(3): 260-273.

Nezan, E., E. Antoine, L. Fiant, Z. Amzil \& C. Billard. 2006. Identification of Pseudonitzschia australis and P. multiseries in the Bay of Seine. Harmful Algae News 31: 1-3.

Ochoa, J. L., A. Sierra-Beltran, A. Cruz-Villacorta \& E. Núñez. 1996. Domoic acid in Mexico. In: Penney, R.W. (ed.). Proceedings of the Fifth Canadian Workshop on Harmful Marine Algae. Department of Fisheries and Oceans. St. John’s, Newfoundland, Canada. pp. 82-90.

Okolodkov, Y. B. 2008. Protoperidinium Bergh (Dinophyceae) of the National Park Sistema Arrecifal Veracruzano, Gulf of Mexico, with a key for identification. Acta Bot. Mex. 84: 93-149.

Okolodkov, Y. B., G. Campos-Bautista, M. L. Parsons, R. Torres-Salgado \& J. A. AkéCastillo. 2009. El género Pseudo-nitzschia (Bacillariophycae) en el Parque Nacional Sistema Arrecifal Veracruzano, Golfo de México: taxonomía y dinámica estacional. In: Resúmenes del Taller sobre Florecimientos Algales Nocivos (FAN): Integración del Conocimiento sobre Eventos de FAN en México, 9-11 de noviembre de 2009, Acapulco, Guerrero. p. 42.

Orlova, T., I. Stonik, N. Aizdaicher, S. Bates, C. Léger \& J. Fehling. 2008. Toxicity, morphology and distribution of Pseudo-nitzschia calliantha, P. multistriata and P. multiseries (Bacillariophyta) from the northwestern Sea of Japan. Bot. Mar. 51: 297-306.

Pan, Y., M. L. Parsons, M. Busman, P. Moeller, Q. Dortch, C. L. Powell, G. A. Fryxell \& G. J. Doucette. 2001. Pseudo-nitzschia pseudodelicatissima - a confirmed producer of domoic acid from the northern Gulf of Mexico. Mar. Ecol. Prog. Ser. 220: 83-92. 
Parsons, M. L., Q. Dortch \& G. A. Fryxell. 1998. A multi-year study of the presence of potential domoic acid-producing Pseudo-nitzschia species in the coastal and estuarine waters of Louisiana, USA. In: Reguera, B., J. Blanco, M. L. Fernández, \& T. Wyatt (eds.). Harmful algae. Proceedings of the VIII International Conference on Harmful Algae. 25-28 June 1997. Vigo, Spain. pp. 184-187.

Parsons, M. L., C. A. Scholin, P. E. Miller, G. J. Doucette, C. L. Powell, G. A. Fryxell, Q. Dortch \& T. M. Soniat. 1999. Pseudo-nitzschia species (Bacillariophyceae) in Louisiana coastal waters: molecular probe field trials, genetic variability and domoic acid analyses. J. Phycol. 35: 1368-1378.

Parsons, M. L., Q. Dortch \& R. E. Turner. 2002. Sedimentological evidence of an increase in Pseudo-nitzschia (Bacillariophyceae) abundance in response to coastal eutrophication. Limnol. Oceanogr. 47(2): 551-558.

Perl, T. M., L. Bedard, T. Kosatsky, J. C. Hockin, E. C. D. Todd \& R. S. Remis. 1990. An outbreak of toxic encephalopathy caused by eating mussels contaminated with domoic acid. New England J. Med. 322: 1775-1780.

Quijano-Scheggia, S., E. Garcés, N. Sampedro, K. Lenning, E. Flo, K. Andree, J. M. Fortuño \& J. Camp. 2008. Identification and characterization of the dominant Pseudonitzschia species (Bacillariophyceae) along the NE Spanish coast (Catalonia, NW Mediterranean). Scientia Mar. 72(2): 343-359.

Quijano-Scheggia, S., E. Garcés, K. Andree, J. M. Fortuño \& J. Camp. 2009. Homothallic auxosporulation in Pseudo-nitzschia brasiliana (Bacillariophyta). J. Phycol. 45: 100107.

Quijano-Scheggia, S., A. Olivos-Ortiz, J. H. Gaviño-Rodríquez, F. Castro-Ochoa, M. Rivera-Vilarelle, M. Galicia-Pérez \& M. Patiño-Barragan. 2011. First report of Pseudo-nitzschia brasiliana and P. micropora (Bacillariophyceae) found in Cuyutlan Lagoon, Mexico. Rev. Biol. Mar. Oceanogr. 46(2): 189-197.

Rhodes, L., C. A. Scholin, I. Garthwaite, A. Haywood \& A. Thomas. 1998. Domoic acid producing Pseudo-nitzschia species educed by whole cell DNA probe-based and immunochemical assays. In: Reguera, B., J. Blanco, M. L. Fernández \& T. Wyatt (eds.). Harmful algae. Proceedings of the VIII International Conference on Harmful Algae. 25-28 June 1997. Vigo, Spain. pp. 274-277.

Rivera, P. 1985. Las especies del género Nitzschia Hassall, sección Pseudonitzschia (Bacillariophyceae), en las aguas marinas chilenas. Gayana Bot. 42(3-4): 9-38.

Sahraoui, I., A. Sakka Hlaili, H. Hadj Mabrouk, C. Léger \& S. S. Bates. 2009. Blooms of the genus Pseudo-nitzschia H. Peragallo in Bizerte Lagoon (Tunisia, SW Mediterranean). Diatom Res. 24: 175-190.

Santoyo, R. H. \& M. Signoret. 1988. Algunas características del fitoplancton de la región marina adyacente de Punta Limón, Veracruz. Anales Esc. Nac. de Cienc. Biol. Méx. 32(1-4): 177-212.

Sarno, D. \& J. Dahlmann. 2000. Production of domoic acid in another species of Pseudonitzschia: P. multistriata in the Gulf of Naples (Mediterranean Sea). Harmful Algae News 21: 5 . 
Schwacke, L. H., M. J. Twiner, S. De Guise, B. C. Balmer, R. S. Wells, F. I. Townsend, D. C. Rotstein, R. A. Varela, L. J. Hansen, E. S. Zolman, T. R. Spradin, M. Levin, H. Leibrecht, Z. Wang \& T. K. Rowles. 2010. Eosinophilia and biotoxin exposure in bottlenose dolphins (Tursiops truncatus) from a coastal area impacted by repeated mortality events. Environ. Res. 110: 548-555.

Scott, F. J. \& D. P. Thomas. 2005. Diatoms. In: Scott, F. J. \& H. J. Marchant (eds.). Antarctic marine protists. Australian Biological Resources Study, Australian Antarctic Division Canberra \& Hobart. pp. 13-201.

Sierra-Beltrán, A. P., R. Cortés-Altamirano, J. P. Gallo-Reynoso, S. Licea-Duran \& J. ÉgidoVillareal. 2005. Is Pseudo-nitzschia pseudodelicatissima toxin the principal cause of sardines, dolphins, sea lions and pelicans mortality in 2004 in Mexico? Harmful Algae News 29: 6-8.

Skov, J., N. Lundholm, R. Pocklington, S. Rosendahl \& Ø. Moestrup. 1997. Studies on the marine planktonic diatom Pseudo-nitzschia 1. Isozyme variation among isolates of P. pseudodelicatissima during a bloom in Danish coastal waters. Phycologia 36(5): 374-380.

Skov, J., N. Lundholm, Ø. Moestrup \& J. Larsen. 1999. Potentially toxic phytoplankton 4. The diatom genus Pseudo-nitzschia (Diatomophyceae/Bacillariophyceae). In: Lindley, J. A. (ed.). International Council for the Exploration of the Sea. Identification Leaflets for Plankton. No. 185. Copenhagen. 23 pp.

Smith, J. C., K. Pauley, P. Cormier, R. Angus, P. Odense, D. O’Neil, M. A. Quilliam \& J. Worms. 1991. Population dynamics and toxicity of various species of Dinophysis and Nitzschia from the southern Gulf of St. Lawrence. In: Gordon, D. C. Jr. (ed.). Proceedings of the Second Canadian Workshop on Harmful Marine Algae. Bedford Institute of Oceanography. Dartmouth, NS, 2-4 October, 1990. Can. Tech. Rep. Fish. Aquat. Sci. 1799. p. 25.

Takano, H. \& K. Kuroki. 1977. Some diatoms in the section Pseudo-nitzschia found in coastal waters of Japan. Bull. Tokai Reg. Fish. Res. Lab. 91: 41-51.

Taylor, F. J. R. \& R. E. Waters. 1982. Spring phytoplankton in the subarctic North Pacific Ocean. Mar. Biol. 67: 323-335.

Trainer, V. L., J. C. Wekell, R. A. Horner, C. L. Hatfield \& J. E. Stein. 1998. Domoic acid production by Pseudo-nitzschia pungens. In: Reguera, B., J. Blanco, M. L. Fernández \& T. Wyatt (eds.). Harmful algae. Xunta de Galicia and the Intergovernmental Oceanographic Comission of UNESCO. Paris. pp. 337-340.

Trainer, V. L., B. M. Hickey \& S. S. Bates. 2008. Toxic diatoms. In: Walsh, P. J., S.L. Smith, L. E. Fleming, H. M. Solo-Gabriele \& W. H. Gerwick (eds.). Oceans and human health: risks and remedies from the seas. Elsevier Science Publishers. New York. pp. 219-237.

Trainer, V. L., M. L. Wells, W. P. Cochlan, C. G. Trick, B. D. Bill, K. A. Baugh, B. F. Beall, J. Herndon \& N. Lundholm. 2009. An ecological study of a massive bloom of toxigenic Pseudo-nitzschia cuspidata off the Washington State coast. Limnol. Oceanogr. 54: 1461-1474.

Vargas-Montero, M. \& E. Freer. 2004. Proliferaciones algales de la diatomea toxigénica Pseudo-nitzschia (Bacillariophyceae) en el Golfo de Nicoya, Costa Rica. Rev. Biol. Trop. 52(1): 127-132. 
Villac, M. C., D. L. Roelke, E. P. Chavez, L. A. Cifuentes \& G. A. Fryxell. 1993. Pseudonitzschia australis Frenguelli and related species from the west coast of the U.S.A.: occurrence and domoic acid production. J. Shellfish Res. 12: 457-465.

Wolny, J. L. \& C. A. Heil. 2005. Pseudo-nitzschia species in Florida coastal waters. Poster presentation at the 3rd Symposium on Harmful Algae in the U.S. October 2-7, 2005. Pacific Grove, California.

Wright, J. L. C., R. K. Boyd, A. S. W. de Freitas, M. Falk, R. A. Foxall, W. D. Jamieson, M. V. Laycock, A. W. McCulloch, A. G. McInnes, P. Odense, V. P. Pathak, M. A. Quilliam, M. A. Ragan, P. G. Sim, P. Thibault, J. A. Walter, M. Gilgan, D. J. A. Richard \& D. Dewar. 1989. Identification of domoic acid, a neurotoxic amino acid, in toxic mussels from eastern Prince Edward Island. Can. J. Chem. 67: 481-490. 